\title{
American Revolutionary War
}

The American Revolutionary War of $1775-1783$ is also termed the War of American Independence. It was caused by economic, social, political, and ideological differences between Great Britain and thirteen of its North American colonies. The first shots were fired at Lexington and Concord in Massachusetts, and campaigns were subsequently waged in New York, New Jersey, and Pennsylvania. However, British defeat at Saratoga in upstate New York in 1777 paved the way for French intervention on the American side (France sought to avenge its defeat by Britain in the Seven Years War of 1756-1763). Thus, what started as an internal revolt within the British Empire now escalated into an international conflict. By 1779 and 1780, respectively, Spain and the United Provinces (the Netherlands) were fighting Britain too. After their debacle at Saratoga, the British war effort in America increasingly moved southwards. The result was that Savanah, Georgia, and Charleston, South Carolina, later fell to British troops. Still, despite their formal victories on the battlefield, the British found it difficult to restore imperial authority amongst the general colonial populous. In 1781 British General Lord Cornwallis was surrounded by US General George Washington and his French allies at Yorktown, Virginia. Cornwallis was later compelled to surrender to his rivals. Although the British still had considerable resources at their disposal, political and economic pressures at home prompted the UK Parliament to end the American War. Thus, by 1783 Britain formally acknowledged the independence of the United States with the Treaty of Paris (although the US Congress had declared independence earlier in 1776). This entry focuses upon the socio-economic consequences of the war in North America.

\section{Economics}

The War of Independence had mixed fortunes for the American economy. Domestic manufacturing was boosted by increased demand for military supplies. Indeed, the revolutionaries opposed importing British goods, and therefore the colonists produced more commodities for themselves (although some Americans still coveted British manufactures). Expanded provision of physical and banking infrastructure, as well as the issuing of paper money by the US Congress and individual states, also stimulated economic activity. The American and British armies bought local produce too. Combined, these factors injected money into the colonial economy. Nevertheless, the conflict generated several economic downsides, not least inflation and rising prices. Some areas of the future United States were physically devastated by the war, as British troops destroyed homes to weaken colonial resolve, and undisciplined American forces requisitioned private property. This invariably resulted in costly reconstruction.

American foreign trade was affected too, as the colonists were now liberated from the British regulatory Navigation Acts. Henceforth, the Americans could trade with greater freedom overseas without having to deal through British middlemen. The rebels also targeted British shipping, which could produce lucrative prizes. Conversely, there were significant drawbacks for colonial trade. American shipping fell victim to British privateers (private ships of war), and therefore the price of shipping insurance rose. British parliamentary subsidies for certain colonial products also ceased. 


\section{Political Activism}

With the breakdown of British authority in the colonies, provincial congresses seized power and installed new state governments. Monarchism was replaced by republicanism, and written constitutions were adopted. This stood in marked contrast with the unwritten British constitution. Assemblies also became larger, thereby enabling frontier towns to acquire greater political representation. Consequently, men of modest backgrounds became increasingly visible in the public arena.

Even so, many of these new regimes continued to broadly follow the old colonial model. Despite some exceptions, most states had a bicameral (two-part) legislature with a single executive or governor. Political rights were still largely confined to property holders. Whilst most states reduced the property qualification for voting, only Pennsylvania and Georgia abolished them entirely.

\section{Class, Deference \& Mobility}

Revolutionary America adopted ideas that were contrary to the Old World. For example, monarchy and hereditary privileges were frowned upon. The US Constitution (ratified by a sufficient number of states in 1788) forbade the creation of titles of nobility. Increased opportunity to purchase cheaper land in the American West also spawned a mobile and commercially-minded society. Respect for authority was eroded too, as revolutionary committees and assemblies contained men from humbler origins than the traditional colonial elite. In addition, military service led to increased social integration. More men were promoted from within the ranks of the US Continental Army, and wealthy citizens served alongside their socio-economic inferiors in state militias.

Yet, for all these changes, there were no significant attempts to radically redistribute wealth. Four of the first five US Presidents were wealthy Virginian landowners. Evidently if Americans accepted the principles of social stratification, they accepted it on the basis of individual merit - as opposed to hereditary privilege.

\section{Identity, Unity \& Dissent}

In several respects, the Revolutionary War contributed towards the development of an American identity. This was made possible through the increased level of physical mobility in the colonies. Indeed, turnpikes and stagecoaches facilitated the movement of people and goods, warfare created refugees, the Continental Army traversed great distances, and militias moved around neighbouring states. In the process, revolutionary and republican ideology was disseminated amongst the people. For many, Congress and the Continental Army symbolised a nation unified in arms, struggling for its independence from a formidable opponent.

However, not all Americans identified with the new order. After resisting imperial control from London, some citizens were less than enthusiastic about a national US Congress. To that end, the Articles of Confederation (which officially took effect in 1781) stated that sovereignty resided in the states. Local identities also survived, and remained vitally important to many inhabitants.

Some colonists were even opposed to the Revolution itself. Hence this conflict was as much a civil war amongst Americans, as it was a struggle with Great Britain. The 
revolutionary John Adams claimed that one third of the population were rebels or Whig patriots, one third neutral, and one third loyal to Britain or Tory. Yet, it is hard to calculate the precise number of loyalists. This is because loyalism manifested itself in different ways, such as neutralism, non-violent opposition, and armed resistance. Whilst many loyalists hailed from socio-economic backgrounds that stood to lose from a rebel victory, they remained a diverse group. Tories ranged from New England merchants dependent upon British trade, to small farmers in the southern backcountry who distrusted coastal elites. Because of their heterogeneous backgrounds, the loyalists were not well-organised, and often relied upon British leadership for direction. Loyalists were often targeted by local committees of safety, subjected to intimidation, and had their properties sold off by new state governments. Such indignities ensured a bloody conflict, especially in the southern backcountry. As many as 100,000 loyalists left the United States to settle overseas in the UK, British North America (Canada), and the West Indies.

\section{Religion}

Religion continued to be as important in the Early Republic as it had been during the colonial era. Nonetheless, the attachment of the Anglican clergy to Britain during the war eroded the ecclesiastical establishment. Thereafter, religious freedom was strengthened in the United States. For example, the war helped to weaken American anti-Catholicism. This was partially because the colonists were being assisted by the Catholic French. Furthermore, US political leaders reaffirmed that religious worship was a private affair. The Bill of Rights (successfully ratified by the states in 1791) forbade Congress from passing laws relating to the establishment of religion.

But the triumph of religious liberty was not easily achieved. Even after the conflict, most New England states continued to require their taxpayers to support public Protestant worship. It was not until the nineteenth century that the Congregational Church was completely disestablished in these states. Whilst the Virginia Statute of Religious Liberty (passed in 1786) guaranteed freedom of conscience, it too had run into significant opposition.

\section{Women}

Colonial America was often a patriarchal society. Henceforth, females were largely excluded from political life, and restricted to home-making and child-rearing. Nor did a married woman control property in her own name. However, American women did play an important role in the disputes between Britain and the thirteen colonies. During the imperial crisis before the war, women often participated in crowds protesting against British parliamentary legislation. They also supported colonial boycotts against imports from the mother country.

The conflict of 1775-1783 affected most American women. Clearly, there were many disadvantages with this situation. Women could face disease or have their homes plundered by billeted troops. But there were some positives too. Whilst their husbands were away, many wives took over as head of the household. This included doing farm work and transacting business. Both sides used women in a supplementary capacity in the armed forces, such as preparing food, cleaning, and serving as nurses. Only rarely did women serve in combat roles. 
The replacement of British monarchism by American republicanism implied that there was scope to reform the traditional roles of women. Hence there were some improvements in the US, such as liberalization of divorce laws. The notion of Republican Motherhood also gained momentum. For a republic to survive it must be virtuous. One way to ensure this was for the mother to instil wholesome values in her offspring, as well as in her husband. As a result, a number of academies were opened for younger women. Although this marked some development in gender relations, and paved the way for future actions, by the late-eighteenth century progress was still qualified. Such academies were relatively few in number, and tended to benefit upper- and middling- social groups. Equally, although Republican Motherhood served a new purpose, it arguably confined women to their traditional domestic roles. The Founding Fathers were generally in no rush to radically amend the status of women - to do so might have invited difficult reforms elsewhere.

\section{African Americans}

The impact of the Revolutionary War upon African Americans varied between the northern and southern colonies. Given that blacks were not an especially large component of the North's population, some whites in that section criticised African slavery prior to the conflict. Quakers published pamphlets decrying African servitude, and northern assemblies occasionally discussed motions banning the trade. However, it was the War of Independence that did more to weaken slavery in this section. Many northerners were struck by the inconsistency of claiming freedom for themselves, whilst denying it to others. Thus, some serious steps were taken to curtail slavery in the North, such as the Vermont Republic prohibiting this practice in its 1777 constitution. Also that year, blacks began to serve in the Continental Army in exchange for their freedom. Despite these gains, however, these reforms were often qualified. Indeed, there had been significant southern opposition towards allowing Africans to enlist in the Continental Army. Eventually, manpower shortages had proven vital in changing attitudes. In addition, northern emancipation was often gradual. It generally did not free adult slaves, but promised to liberate their children when they came of age. Even as late as 1860, eighteen elderly slaves still resided in New Jersey. The most important limitation to these changes was that they did not affect the majority of African Americans, who resided in the South.

The labour of African Americans was vital to the southern plantation economy. Traditionally, limits had been placed upon the legal status of slaves, as well as their education and freedom of movement. When the British war effort moved southwards, it posed significant challenges to the slave-holding regime. Many Africans were taken away by their white masters, whilst some slaves attempted to remain neutral. This latter approach could prove risky as armies and militias on both sides might harass slaves. Other blacks took flight to the North, left for Florida (which under the British and Spanish had been a haven for runaways), or established runaway (maroon) communities in remote areas. Lord Dunmore, the British governor of Virginia, paved the way for African recruitment into the British army. His proclamation of November 1775 promised to free any Virginian slave who fled their rebel masters to serve Britain. Such a move was calculated to weaken the southern economy, and to diminish the region's fighting capability. It therefore hardened the resolve of white southern rebels. Although the British welcomed the assistance of runaway slaves, they did not seek to overturn the practice of slavery. In the eventuality of a British victory, the UK hoped to rebuild the South's economy - and slavery would invariably 
play a role in this. A few African American loyalists attained their freedom, and they moved to Nova Scotia. But frustrated by intolerance and poor land, many African loyalists subsequently migrated to Sierra Leone - a British colony in West Africa.

\section{Native Americans}

The western frontier of the American colonies was a long-standing source of contention. In theory, the British had placed restrictions upon further colonial westward migration with the 1763 Proclamation Line. But the settlers were eager for more land, and continued to advance even as far as the Ohio River Valley. The War of Independence had a major impact upon the frontier. Some natives favoured neutrality, whilst others went over to the Americans. However, some tribes supported Britain, fearing that a colonial victory would result in unlimited westward migration and competition with indigenous peoples. The British were equally keen to cultivate relations with American Indians to boost their troop numbers. Often with British encouragement, the natives attacked colonial settlements. But in 1776 the Cherokees acted against British advice, and attacked the frontiers of Virginia and the Carolinas. Rebel counter-attacks were subsequently launched by the Continental Army and individual states. The frontier war was replete with brutality on both sides. Britons and Americans were especially critical of the native practice of scalping their victims.

As the conflict ended, the British gradually withdrew their support from native tribes. Therefore, many American Indians opted to reach an accommodation with the United States, and treaties were later signed. However, in the area between the Ohio River and south of the Great Lakes - known by contemporaries as the Northwest Frontier - the Chippewas, Delawares, Shawnees, Ottawas, Potawatomis, and Miamis, formed the Western Confederacy. They continued to resist white encroachment, and the struggle for control of the Northwest initially went badly for the United States. But, after a reversal in fortunes, the western tribes signed the Treaty of Greenville in 1795. This document ceded native claims to most of the land in Ohio, which helped pave the way for continued US westward expansion during the nineteenth century.

Simon Hill, Liverpool John Moores University, UK

See Also:

Imperialism; United Kingdom; United States; Wars in the British Empire; Wars of Colonial Independence

Further Readings:

Cogliano, Francis D. Revolutionary America 1763-1815: A Political History. London: Routledge, 2000. 
Conway, Stephen. The War of American Independence 1775-1783. London: Edward Arnold, 1995.

Foner, Eric. Give Me Liberty! An American History. London: Norton, 2014.

Greene, Jack P. The American Revolution: Its Character and Limits. New York: New York University Press, 1987.

Jones, Maldwyn A. The Limits of Liberty: American History 1607-1992. Oxford: Oxford University Press, 1995.

Morgan, Gwenda. The Debate on the American Revolution. Manchester: Manchester University Press, 2007.

Wood, Gordon S. The Radicalism of the American Revolution. New York: Random House, 1991. 